\title{
A new species of Exochomoscirtes PIC, 1916 from Malaysia (Insecta: Coleoptera: Scirtidae) with biological notes on the bamboo-inhabiting members of the genus
}

\author{
With 21 figures and 3 tables
}

Damir Kovac ${ }^{1}$ and Bernhard Klausnitzer ${ }^{2}$

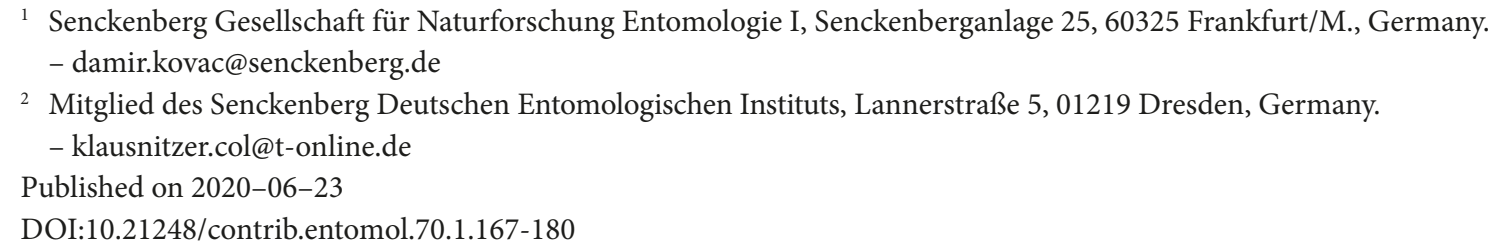

\begin{abstract}
Seven Exochomoscirtes species inhabiting phyto- or lithotelmata in West Malaysia and North Thailand were reared from larvae. E. hashimi spec. nov. from W. Malaysia was described and E. carinensis and E. meghalayensis were new records for Thailand. Larvae of E. meghalayensis inhabited water-filled tree holes and forest rock pools, while E. hajeki, E. jaechi, E. chiangmaiensis, E. carinensis, E. cf. luteosuturaloides and E. hashimi spec. nov. occurred in water-filled bamboo stems. Bamboo-inhabiting species occupied different types of bamboo habitats such as mature bamboo stems (inhabited internodes up to $21 \mathrm{~m}$ high), dead bamboo stems or bamboo stumps. Internodes of nutrient-rich bamboo shoots were not colonized. Adult Exochomoscirtes entered enclosed internode cavities through holes created by insects, woodpeckers and other animals or cracks in bamboo walls. Larvae living in open phytotelmata such as water-filled tree holes or bamboo stumps created pupal chambers made of soil or detritus in the vicinity of their habitats. In species inhabiting enclosed internodes pupal chambers were absent. Larvae pupated inside the internodes firmly attached to the bamboo walls close above water surface. Total development time of bamboo-inhabiting species was about 3 months. Predators of Exochomoscirtes species dwelling in enclosed internodes were chironomid larvae (Dasyhelea), mosquito larvae (Toxorhynchites), small water striders (Lathriovelia), rove beetles (Acylophorus), jumping spiders (Paracyrba), web-building spiders (Theridiidae) and web-building larvae of fungus gnats (Truplaya).
\end{abstract}

\section{Taxonomic acts}

E. hashimi spec. nov.- urn:lsid:zoobank.org:act:4D2AA5A6-DB2D-4B5F-AE91-E8C985FFA4DD

\section{Key words}

Scirtidae, Exochomoscirtes, Malaysia, Thailand, new species, new records, phytotelmata, lithotelmata, bamboo, life cycle, predators 


\section{Zusammenfassung}

Sieben phyto- und lithotelmen-bewohnende Exochomoscirtes-Arten aus West-Malaysia und Nord-Thailand wurden gezüchtet. E. hashimi spec. nov. aus West-Malaysia wurde beschrieben, und E. carinensis and E. meghalayensis waren Neunachweise für Thailand. Die Larven von E. meghalayensis lebten in wassergefüllten Baumlöchern und Felsenbecken, während E. hajeki, E. jaechi, E. chiangmaiensis, E. carinensis, E. cf. luteosuturaloides und E. hashimi spec. nov. in wassergefüllten Bambushalmen vorkamen. Bambusbewohnende Arten bevorzugten verschiedene Typen von Bambushabitaten, z. B. ausgewachsene Bambushalme (bewohnte Internodien bis $21 \mathrm{~m}$ hoch), tote Bambushalme oder Bambusstümpfe. Internodien nährstoffreicher Bambusschösslinge wurden nicht besiedelt. Adulte Exochomoscirtes gelangten in abgeschlossene Bambusinternodien durch Löcher, die von Insekten, Spechten oder anderen Tieren erzeugt wurden, oder durch Risse in der Bambuswand. Larven, die sich in offenen Phytotelmen wie wassergefüllten Baumlöchern oder Bambusstümpfen entwickelten, bauten Puppenkammern aus Erde oder Detritus in der Nähe ihrer Habitate. Larven, die in geschlossenen Internodien lebten, bauten keine Puppenkammern. Sie verpuppten sich in den Internodien-Hohlräumen und hefteten sich an die Bambuswand dicht über der Wasseroberfläche. Die Gesamt-Entwicklungszeit der bambusbewohnenden Arten betrug etwa drei Monate. Fressfeinde von ExochomoscirtesArten, die in abgeschlossenen Internodien lebten, waren Chironomidenlarven (Dasyhelea), Stechmückenlarven (Toxorhynchites), Wasserläufer (Lathriovelia), Kurzflügelkäfer (Acylophorus), Springspinnen (Paracyrba), netzbauende Spinnen (Theridiidae) und netzbauende Larven von Langhornmücken (Truplaya).

\section{Introduction}

Marsh beetles (Scirtidae) of the genus Exochomoscirtes PIC, 1916 are small $(2.20-5.90 \mathrm{~mm})$, rounded beetles that have enlarged hind femora and are capable of jumping. Their elytra are uniformly yellow, brown or black colored or brightly patterned with red, orange, yellow or black spots.

The genus is distributed in the Oriental Region with most species occurring in Southeast Asia. One species extends to New Guinea and Australia and one species is confined to Japan (Ruta \& Yoshitomi 2010). Six species are perhaps Palaearctic, because they have only been recorded from the northern border of the Oriental Region.

Ruta \& Yoshitomi (2010) presented a revision of the genus Exochomoscirtes and recognized 35 species. Since then eleven new species have been described: three species from Laos, Northeast India and Java (KLAUsNITZER 2010b), two from Laos and Nepal/North India (Klausnitzer 2010c), one from Thailand (Ruta 2011a), two from Malaysia and Myanmar (Ruta 2011b) and three from Palawan, Philippines (ZwICK 2011).

Exochomoscirtes larvae are aquatic detritus feeders living in phytotelmata, i.e., small water bodies in plants. Larval habitat was known in 7 out of 46 species. Five species were recorded from water-filled tree holes and buttress roots (E. fuscus, E. niger, E. palawanicus, E. ruforotundus, E. takizawai; Ruta \& Yoshiтомi 2010, Zwick 2011) and three species from bamboo internodes (E. ruforotundus, E. discoidalis and E. klausnitzeri; Ruta \& Yosнiтom 2010, WATTS 2004).

In the present paper we describe Exochomoscirtes hashimi spec. nov. and outline the biology of seven mainly bamboo-inhabiting Exochomoscirtes species from Malaysia and Thailand, particularly their habitat preferences, life cycles and predators.

\section{Materials and methods}

Field study sites and collecting. In West Malaysia field work was carried out in 1989, 1991, 1993, 1994 and 1995. The study site was located at the Ulu Gombak Field Study Centre (UFSC) of the University of Malaya (West-Malaysia, Selangor Darul Ehsan). In north Thailand observations were carried out in 2011, 2012 and 2014. The collecting sites were located in the Mae Hong Son Province, district of Pangmapha. Bamboo host species were Gigantochloa scortechinii GAMBLE (West Malaysia), Bambusa polymorpha Munro, Dendrocalamus strictus (RoxBURGH) NeEs and other Dendrocalamus spp. and Cephalostachyum pergracile Munro (North Thailand).

Exochomoscirtes larvae were collected from water-filled bamboo internodes, tree holes and forest rock pools. Larvae were retrieved by taking out leaves and inspecting the leaf surface and by sucking up water and detritus with a large pipette. Subsequently, larvae were hand sorted from a flat tray using a pair of soft tweezers. The larvae were transported to the laboratory in plastic bags containing wet leaves. Bamboo internodes were investigated both in Malaysia and Thailand, water-filled tree holes and rock pools only in Thailand.

For collecting specimens from living bamboos, culms were felled and internodes cut open with a saw and a large knife (parang). The height of the colonized internodes, internode dimensions, amount of water as well as the size and shape of naturally occurring holes in the bamboo wall were recorded.

Breeding. In laboratory larvae were kept in water-filled cut bamboo internodes containing detritus from the place of origin. The bamboo containers were placed in tightly sealed plastic boxes as protection against ants and in order to prevent larvae from escaping. The bottom of 
the plastic boxes was covered with moistened tissue, thus providing a hiding place for pupating larvae and keeping the air humidity high. Temperature and light conditions in the laboratory were about the same as in the field, i.e., $23-33^{\circ} \mathrm{C}$ in Malaysia and $20-36^{\circ} \mathrm{C}$ in North Thailand. Breeding boxes were inspected daily. Freshly eclosed beetles were isolated and kept alive for at least three days until they were fully pigmented.

Long-term observations in the field. Natural succession, occurrence of different developmental stages and predators of Exochomoscirtes and other bamboo inhabitants were investigated during 3 long-term studies in Malaysia employing the giant bamboo Gigantochloa scortechinii:

a) Long-term study I. For observations of Exochomoscirtes larvae living in dead bamboo culms 100 internodes were used ("experimental internodes", see Kovac \& STREIT 1996). Experimental internodes had a lid which could be opened or closed for examination or collecting of prey items (Fig. 16).

Ten bamboo culms, each containing 10 experimental internodes were set up in a horizontal position at different locations in the vicinity of the UFSC. Experimental internodes were checked daily over a period of more than six months (1991-05-18 until 1991-12-07) in order to record, whether Exochomoscirtes adults, larvae or pupae were present in the internodes. Predators feeding on Exochomoscirtes specimens were collected together with their prey and identified in the laboratory.

b) Long-term study II. For observation of Exochomoscirtes larvae inhabiting mature bamboo culms ( 2 years or older) hundred $9 \mathrm{~mm}$ circular holes were bored in lower internodes of bamboo culms using a battery-operated drill. The holes were bored in August 1993 and the cavities were checked using an endoscope once a week for more than two months between 1994-06-07 and 1994-08-16. Specimens could not be retrieved from the internodes for identification during the ongoing study.

c) Long-term study III. For observation of internode cavities in bamboo shoots (height ca. $3 \mathrm{~m}$ or taller) hundred circular holes were drilled in the same way as above and internode cavities were checked daily by an endoscope for 4.7 months between 1993-08-13 and 1994-01-4.

Preservation, preparation, terminology and depositories. Fully pigmented adults were killed with ethanol acetate and mounted on cards or preserved in $70 \%$ ethanol. Larvae and pupae were preserved in $70 \%$ ethanol. For genital examination the abdomen was cleared in cold $\mathrm{KOH}(4 \%)$ and genitalia mounted on microscop slides in Euparal.
Terminology follows KLausnitzer (2009) and Ruta \& Yoshitomi (2010). Measurements are given in millimetres.

Type material is deposited in Senckenberg Deutsches Entomologisches Institut (Holotypus) and in coll. KLAUSNitzer (Paratypus).

\section{Results}

\section{Taxonomy and Faunistics}

\section{Exochomoscirtes hajeki RuTA, 2011}

Material examined: $1 \sigma^{x}$, Pangmapha, near Ban Nam Rin, 2011-11-25, in decaying bamboo stem, internode with narrow slit, B1/11b; $10^{*}$, Malaysia, Selangor Darul Ehsan, Genting Highlands, 1991-05-06, ca. 1000 m, dead bamboo culm (experimental internode), BHe1; $10^{\star}$, Selangor Darul Ehsan, Ulu Gombak Field Studies Centre, 1991-11-07, 250 m, dead bamboo culm of Gigantochloa scortechinii (experimental internode), BHe5; $10^{\text {* }}+$ 2 specimens (1 ex larva), Ulu Gombak, Field Studies Centre, 1999-09-13, rotting bamboo internode; all leg. D. Kovac.

Habitat: Water-filled decaying bamboo internodes with small holes.

Host plants: Bambusa polymorpha, Cephalostachyum pergracile, Dendrocalamus sp., Gigantochloa scortechinii.

Distribution: Malaysia (Perak, Cameron Highlands, so far only known from type locality, (Ruta 2011b). First record for Thailand.

\section{Exochomoscirtes jaechi RUTA \& Yoshitomi, 2010}

Material examined: $1 \sigma^{*}$ (ex larva), Thailand, Mae Hong Son, Pangmapha, near Ban Pha Mon, larva collected on 2011-11-2, adult eclosed on 2011-11-12, in bamboo stump, Z13/3/11b; 1 o $^{\star}, 1$ 우 (ex larvae), Pangmapha, near Pha Mon, larvae collected on 2014-06-07, adults emerged on ca. 2014-06-18, in forest rock pool, Z 26/3/14a; all leg. D. Kovac.

Habitat: Dead bamboo stems with large openings, bamboo stumps, forest rock pools.

Distribution: N Thailand (Chiang Mai prov., RuTA \& Yosнiтомi, 2010 and Mae Hong Son prov., present study), Laos (Bolixhamxai prov., Ruta \& Yoshitomi, 2010).

Host plant: Bambusa polymorpha. 


\section{Exochomoscirtes chiangmaiensis RUTA, 2011}

Material examined: $1 \sigma^{\star}$ (ex larva), Thailand, Mae Hong Son, Pangmapha, near Ban Nam Rin, larva collected on 2011-10-21, adult emerged on 2011-10-27, water-filled bamboo stump, Z 19/1/11b, leg. D. Kovac.

Habitat: Bamboo stumps.

Host plant: Bambusa polymorpha, Dendrocalamus sp.

Distribution: Thailand (Chiang Mai prov., Ruta 2011a and Mae Hong Son prov., present study).

\section{Exochomoscirtes carinensis RUTA, 2011}

Material examined: $1 \sigma^{*}, 1 \%$ (both ex larva), Thailand, Mae Hong Son, Pangmapha, near Ban Rai, larvae collected on 2011-11-03, adults emerged on 2011-11-11, in water-filled bamboo stump, Z 25/2/11b, leg. D. Kovac.

Habitat: Water-filled bamboo stumps.

Host plant: Dendrocalamus spec.

Distribution: Myanmar ("Carin"), so far only known from type locality (RUTA 2011b). First record for Thailand.

\section{Exochomoscirtes meghalayensis RUTA \& YOSHITOMI,} 2010

Material examined: $1 \sigma^{\star}$ (ex larva), Thailand, Mae Hong Son, Pangmapha, near Soppong, larvae collected on 2011-11-02, adult emerged on 2011-11-12, in water-filled depressions on big fallen tree, Z 24/2/11b; 1 ㅇ (ex larva), from the same batch of larvae as before, adult emerged on 2011-11-17, Z 24/4/11b; from the same batch of larvae as before, adult emerged on 2011-11-24, Z 24/5/11b; 1 i (ex larva), Pangmapha, near Ban Pha Mon, larvae collected on 2011-11-13, adult emerged on 2011-11-19, Z 8/14/11b; all leg. D. Kovac.

Habitat: Tree holes and rock pools.

Distribution: NO-India (Meghalaya), so far only known from two specimens from the type locality (RutA \& Yosнiтомi, 2010). First record for Thailand.

\section{Exochomoscirtes cf. luteosuturaloides RUTA \& YOSHITOMI, 2010}

Material examined: 2 우 (1 specimen ex larva), Malaysia, Selangor Darul Ehsan, Ulu Gombak Field Studies Centre, 1989-04-30, dead bamboo stem, leg. D. Kovac.
Habitat: Water-filled internodes of living or dead bamboo culms.

Host plant: Gigantochloa scortechinii.

Distribution: Malaysia (Sabah), only known from one male (Ruta \& Yoshiтomi, 2010).

\section{Exochomoscirtes hashimi KLAUSNITZER Spec. nov. urn:Isid:zoobank.org:act:4D2AA5A6-DB2D-4B5F-AE91-E8C985FFA4DD}

Holotype: $\sigma^{\top}$ (ex larva), Malaysia, Selangor Darul Ehsan, Ulu Gombak Field Studies Centre, 1989-0430, water-filled internode in dead bamboo stem, leg. D. Kovac.

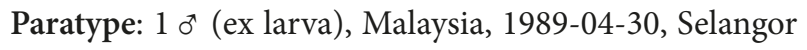
Darul Ehsan, Ulu Gombak Field Studies Centre, waterfilled internode in dead bamboo stem, leg. D. Kovac.

Habitat: Water-filled dead bamboo stems with small holes or cracks in the wall.

Host plant: Gigantochloa scortechinii.

Distribution: Peninsular Malaysia (Selangor Darul Ehsan).

Body uniformly reddish brown (Fig. 1), oval (total length/ greatest body width = Holotype: 1.50; Paratype: 1.71 ) . Total length = Holotype: $4.72 \mathrm{~mm}$; Paratype: $4.69 \mathrm{~mm}$.

Head densely and finely punctate; pilosity dense, somewhat protruding and light-colored. Distance between eyes $0.67 ; 0.63 \mathrm{~mm}$. Antenna reddish brown.

Pronotum densely and finely punctate, surface between punctures smooth (x 100 magnification); pilosity dense and light-colored, especially on front and side margins. Length in the center of pronotum $0.77 ; 0.79 \mathrm{~mm}$; maximum width of pronotum $2.00 ; 1.98 \mathrm{~mm}$. Scutellum punctate and pilose as pronotum.

Elytra punctate as pronotum, surface between punctures smooth (x 100 magnification), pilosity light-colored, with faint marks of two longitudinal ridges. Maximum width of elytra $3.14 ; 2.75 \mathrm{~mm}$; maximum length of elytra $3.95 ; 3.90 \mathrm{~mm}$.

Larger metatibial spur straight, only apex slightly curved, length $0.47 ; 0.42 \mathrm{~mm}$; shorter spur slightly curved, length $0.27 ; 0.24$. Length of metatibia $1.30 \mathrm{~mm}$, length of first segment of metatarsus $0.50 \mathrm{~mm}$.

Sternites yellowish brown; front edges of sternites 3-6 narrow dark brown. Posterior margin of sternite 7 slightly truncate in middle (Fig. 2). Total length $1.71 ; 1.47 \mathrm{~mm}$; greatest width $0.57 ; 0.51 \mathrm{~mm}$.

Sternite 9 composed of two oblong sclerites, tapering caudally, densely covered with bristles at apex. Sternite 9 truncate between sclerites (Fig. 3). Each hemisternite weakly reinforced by a rod-shaped structure located in centre front. Shape of sternite 9 resembles Elodes: a narrow 
shaft, broad plate parallel on sides, caudally covered with setae. Total length of sternite 9: $0.47 ; 0.52 \mathrm{~mm}$; greatest width $0.18 ; 0.21 \mathrm{~mm}$.

Tergite 7 composed of a broad plate and strongly sclerotized Bacilla lateralia curved inward (Fig. 4). Central part of posterior edge sclerotized and truncate (rear width of tergite 7: $0.10 \mathrm{~mm}$ ), tapering into inclined, pointed apices (front distance between apices $0.18 \mathrm{~mm}$ ) (Fig. 5). Tergite 8 composed of a rounded plate with indented posterior margin and strongly sclerotized, very faintly curved Bacilla lateralia, which are arched and interconnected in the center of the plate (Fig. 6). Edge of indentation $0.04 \mathrm{~mm}$ deep, bearing small teeth. Total length of tergite $8: 1.05 ; 0.97 \mathrm{~mm}$; greatest width of plate $0.53 ; 0.60 \mathrm{~mm}$. Length of Bacilla lateralia $0.88 ; 0.90 \mathrm{~mm}$. Plate of tergite 9 weakly sclerotized, rear part densely covered with pointed microtrichia. Bacilla lateralia almost straight (Fig. 7). Total length of tergite 9: 0.60; $0.62 \mathrm{~mm}$; greatest width of plate $0.31 ; 0.32 \mathrm{~mm}$.

Tegmen with transverse capulus, indented on sides (width $0.26 ; 0.20 \mathrm{~mm}$ ). Parameres outwardly directed, approximately half-way angled inwards (Fig. 8), lobe-shaped in posterior part. Middle projection almost 3/4 as long as parameres, apically rounded. Total length of tegmen 0.43 ; $0.47 \mathrm{~mm}$; greatest width $0.36 ; 0.24 \mathrm{~mm}$; Length of middle projection from base $0.22 ; 0.23 \mathrm{~mm}$.

Penis with triangular pala and narrow edge, almost straight in front, tapering backward (Fig. 9). Parameroides distinctly separated. Total length of penis $0.36 ; 0.35 \mathrm{~mm}$; greatest width of pala $0.13 ; 0.12 \mathrm{~mm}$.

Etymology: The species is named after Dr. Rosli Hashim from the University of Malaya, who supported DK in the field in his capacity as head of the Ulu Gombak Field Studies Centre.

\section{Diagnosis}

Body oval, elytra monochromatic, color of elytra and pronotum identical, antenna filiform. Metatibia lacking specific modifications. Special feature present on posterior margin of tergite 7 , namely a truncate, elevated sclerotized structure, which is not prolonged caudally (Figs 4,5). The sclerotized structure on tergite 7 suggests a comparison between E. hashimi spec. nov. and four Exochomoscirtes species possessing a process in the same position. In E. quadripartitus Ruta \& Yoshiтomi, 2010 and E. sondaicus Klausnitzer, 2010 the process has a complicated structure, while in E. retusus (CHAMPION, 1918) and E. ruforotundus (WATTs, 2004) the process is rectangular. A comparison of the two latter species with E. hashimi spec. nov. shows (Table 2), that especially the tegmen of E. retusus and E. hashimi spec. nov. are similar, while the posterior margins of tergite 7 are totally different. The shape of penis and further details of tegmen are also different. E. hashimi spec. nov. is also well distinguishable from other Exochomoscirtes species on the basis of size and proportions of tergite 8 , indentation on tergite 8 bearing small teeth (Fig. 6), and the shape of sternite 9 (Fig. 3).

Habitat: Water-filled internodes of decaying bamboo culms.

Host plant: Gigantochloa scortechinii.

Distribution: West Malaysia.

\section{Biology}

Habitat: As indicated in Table 2 Exochomoscirtes larvae were collected from water-filled tree holes (Fig. 10), depressions in fallen trees (Fig. 11) forest rock pools (Fig. 17) and bamboo internodes in mature culms (Fig. 12), dead culms (Fig. 13) or bamboo stumps (Fig. 14).

Enclosed bamboo internodes (in contrast to open bamboo stumps) were colonized through holes made by insects, woodpeckers or small mammals. Entrance holes in bamboo shoots were made by moth larvae belonging to Crambidae (Lepidoptera; hole size $3 \times 2 \mathrm{~mm}$ ) or Chrysomelidae (Coleoptera; in Malaysia: Lasiochila goryi (GuÉRIN-Méneville, 1840)); hole size ca. 6 x $3 \mathrm{~mm}$, Fig. 12). In mature culms holes were created by Cerambycidae (Coleoptera; Abryna regispetri PaIVA, 1860, circular hole, ca. $1 \mathrm{~cm}$ in diameter) and woodpeckers (feeding holes of different sizes and entrances of nesting internodes, ca. $6 \times 4 \mathrm{~cm}$ ).

Cracks in the wall, for example, narrow slits which resulted from splitting of dead bamboo culms due to low humidity in the dry season were also suitable as entrance openings. The narrow slits were almost as long as the internodes and 1-2 mm wide. They were located approximately in the middle of the fallen, more or less horizontal dead bamboo culms (Fig. 13), thus allowing water to collect at the bottom of the internodes.

In dead bamboo culms Exochomoscirtes hajeki and E. hashimi spec. nov. were common, while Exochomoscirtes cf. luteosuturaloides was rare and E. jaechi and E. chiangmaiensis/carinensis were found only once. The latter two species were found in the same internode possessing a large opening created by a fallen tree branch (Fig. 15). During the long-term study I (see Methods) 86 out of 100 internodes were occupied by Exochomoscirtes 6 months after the holes were bored. In 31 internodes E. hajeki hatched out, in 15 internodes E. hashimi spec. nov. and in one internode E. cf. luteosuturaloides. Specimens inhabiting the remaining occupied internodes could not be determined, because they were still in the larval stage at the end of the study period. In most internodes freshly emerged adults belonged just to one Exochomoscirtes species, but in one case E. cf. luteosuturaloides and E. hajeki were reared from the same internode. 
In mature bamboo culms larvae of E. cf. luteosuturaloides were found in a deserted nesting internode of a woodpecker. The base of the inhabited internode was $20.86 \mathrm{~m}$ above ground. During the long-term study II (see Methods) sixty-nine out of hundred internodes were occupied by Exochomoscirtes larvae ca. 13 months after the holes were bored. During the relatively short observation period (about two months, checks once per week) only six freshly eclosed Exochomoscirtes adults were observed. They probably belonged to E. hashimi spec. nov., however, specimens could not be retrieved from the internodes for accurate determination. Sometimes, large and very small Exochomoscirtes larvae were found in the same internodes. In felled bamboo culms the water amount was less than $600 \mathrm{ml}$ per internode in the rainy season in Malaysia, while in the dry season many internodes were dried up.

Exochomoscirtes larvae were never found in bamboo shoots, neither in freshly felled shoots both in Malaysia and Thailand, nor during the long-term study III, in which 100 shoot internodes were observed daily for more than 4 months.

In bamboo stumps E. chiangmaiensis / E. carinensis were most common. These two species looked very similar and could only be distinguished by male genitalia. Other species found in bamboo stumps were Exochomoscirtes jaechi $(\mathrm{n}=1)$ and E. hajeki together with E. chiangmaiensis / E. carinensis $(\mathrm{n}=1)$.

\section{Behaviour and life cycle}

Exochomoscirtes larvae were hidden between debris in the daytime (especially in open phytotelmata), while in the night time they walked around on the bottom of the internodes, on the internode walls or underside of the water surface. Submerged specimens carried an air bubble at the tip of their abdomen (Fig. 16) and replenished their air supply at the water surface from time to time. Larvae fed on detritus at the bottom of the internodes, on the internode walls or under the water surface. In experimental internodes there were about 20-30 larvae per internode.

Mature Exochomoscirtes larvae climbed on land for pupation and had their long antennae broken off (Fig. 18). Larvae living in open phytotelmata pupated in crevices or in the ground in the vicinity of their habitats. Prior to pupation they always constructed pupal chambers made of soil or debris (Fig. 18). In E. chiangmaiensis pupal chambers were found on the outside wall of bamboo stumps $(\mathrm{n}=3)$ or inside the bamboo stump ca. $3 \mathrm{~cm}$ above the water surface $(n=1)$.

In enclosed bamboo internodes larvae pupated inside the internode cavities (Exochomoscirtes hajeki, E. cf. luteosuturaloides and E. hashimi spec. nov.). They pupated ca. 2 days after leaving water. The pupae were freely attached to the bamboo wall $1-2 \mathrm{~cm}$ above the water surface with their heads pointing downwards
(Figs 17, 19). If disturbed, they reacted by fierce up and down movements of their bodies. In rare cases mature larvae of Exochomoscirtes hajeki, E. cf. luteosuturaloides, and E. hashimi spec. nov. started to build a pupal chamber, but they usually did not finish it. Thus, pupae were surrounded by an oval wall made of debris (Fig. 19). In laboratory larvae of all species pupated between moist tissues, because there was no material available for the construction of pupal chambers.

Colonization and development of Exochomoscirtes inhabiting dead bamboo culms was observed during the long-term study I ("experimental internodes", see methods and Fig. 16). In general, adult beetles stayed on the internode wall close above the water surface and remained in the internode cavities just for one day. Eggs were not detected in the field, but 22 tiny eggs and 5 freshly hatched larvae were found in a vial containing one E. cf. luteosuturaloides female. The first two Exochomoscirtes beetles, E. hajeki and E. hashimi spec. nov., arrived six days after beginning of the observation. The first relatively large larvae were detected 25 days after beginning of the observation. The period from the first larval observation to the first observation of pupae in the respective internodes was 69/63/79/64/ 78/ 64 days (E. hajeki) and 74/67/ 81 days (E. hashimi spec. nov.).

Exochomoscirtes larvae pupated about two days after they had left water. Pupal stage lasted 2-4 days: E. hashimi spec. nov.: $2-3$ days $(\mathrm{n}=14)$, E. hajeki: $3-4$ days $(\mathrm{n}=4)$, E. chiangmaiensis/carinensis 4 days $(\mathrm{n}=2)$ and E. meghalayensis: $2-4$ days $(\mathrm{n}=4)$. The period between the beginning of the long-term study (boring of the holes) and the first detection of freshly emerged adults in different internodes was 100-135 days $(n=16)$. In two internodes the period between detection of a probably egg-laying female and eclosion of the first adult belonging to E. hajeki was 88 and 95 days.

\section{Predators}

Fifty-two predators were collected from dead or living internodes during the long-term studies I and II (see Methods). They fed on Exochomoscirtes when the internodes were inspected or the prey items were detected in spider or mycetophilid nets. Captured Exochomoscirtes adults belonged to E. cf. luteosuturaloides, E. hajeki and E. hashimi spec. nov.

Table 3 shows that all Exochomoscirtes stages inhabiting experimental internodes were preyed upon by various aquatic, semi-aquatic or terrestrial predators. Small Exochomoscirtes larvae were quickly grabbed by aquatic larvae of the tiny midge Dasyhelea KIEfFer, 1911 (Diptera, Chironomidae), which slowly crawled at the bottom of the internode. Larger Exochomoscirtes larvae were preyed upon by mosquito larvae belonging to Toxorhynchites metallicus LeICEster, 1904 and T. leicesteri Theobald, 1904 (Diptera, Culicidae). They 
hunted Exochomoscirtes larvae at the bottom of the internodes as well on the side walls or underside of the water surface.

The small waterstrider Lathriovelia rickmersi KovAC \& YANG, 2000 (Heteroptera, Veliidae) seized Exochomoscirtes larvae walking on the underside of the water surface (Kovac \& Krocke 2013). The semiaquatic rove beetle Acylophorus NordmAnN, 1837 (Coleoptera, Staphylinidae) hunted on or near the edge of the water surface and seized Exochomoscirtes larvae replenishing their air supply, climbing on land for pupation or pupae attached to the bamboo wall.

The terrestrial jumping spider Paracyrba wanlessi ZABKA \& Kovac, 1996 (Araneae, Saltididae) seized submerged Exochomoscirtes larvae from the edge of the water surface as well as larvae climbing on land, pupae or freshly emerged adults (ZABKA \& KovaC 1996). Web-building spiders (Theridiidae) captured Exochomoscirtes larvae crawling on land or pupae and deposited them in their webs.

In living bamboo culms Exochomoscirtes adults were hunted by larvae of Toxorhychites magnificus (LEICESTER), 1908, web-building Theridiidae and larvae of the mycetophilid fly Truplaya ferox Kovac \& Matile, 1997 (Diptera, Keroplatidae), which constructed slimy webs in the terrestrial part of the internode cavities (Kovac \& Matile 1997).

\section{Discussion}

Exochomoscirtes species were known to inhabit waterfilled trees holes, buttress roots and bamboo internodes (Watts 2004, Ruta \& Yoshitomi 2010, Zwick 2011). In the present study larvae were also detected in depressions of large fallen trees (Fig. 11), forest rock pools (Fig. 17) and different types of bamboo phytotelmata, for example, internodes of mature culms up to a height of ca. $20 \mathrm{~m}$.

The main focus of the study was on the ecology and biology of Exochomoscirtes species inhabiting bamboo. Bamboo phytotelmata were divided into sub-habitats on the basis of the accessibility of bamboo internodes (open internodes vs. enclosed internodes possessing small entrance holes), availability of nutrients and durability of the habitats. In preceding studies different bamboo habitat types were found to harbour different animal communities (Kovac \& Streit 1996).

Bamboo shoots were a short-lived habitat existing just for a few weeks or months, mature bamboo culms existed up to ten years and were colonized by Exochomoscirtes over and over again and dead bamboo culms or bamboo stumps decomposed or were not functional after 1-2 years, depending on the position of the culm (upright or lying on the ground) and humidity (KovAC \& STREIT 1996). In open phytotelmata such as bamboo stumps or water-filled tree holes nutrient input consisted mainly of fallen leaves, while in enclosed bamboo internodes (smallest entrance holes $3 \times 2 \mathrm{~mm}$ ) nutrient input consisted of dead bamboo inhabitants, material brought into the internode cavities for example by ants or substrate from decomposing bamboo walls. Most bamboo phytotelmata, especially water-filled internodes of mature bamboo culms, were nutrient-poor, whereas the soft-walled bamboo shoot phytotelmata were nutrient-rich (Kovac \& STREIT 1996).

Although the number of habitat records was small, it seems that Exochomoscirtes species preferred certain phytotelmata types (Table 2). Thus, E. meghalayensis larvae only occurred in water-filled tree holes and rock pools, E. hajeki was abundant in enclosed internodes of dead bamboo culms and E. chiangmaiensis and E. carinensis were most common in bamboo stumps. E. hashimi spec. nov. was abundant in dead bamboo internodes and perhaps even more common in living bamboo culms, since all emerged adults observed during the longterm study II were E. hashimi spec. nov. It is noticeable that Exochomoscirtes larvae were always absent in nutrient-rich bamboo shoot internodes.

Species primarily inhabiting open phytotelms apparently did not colonize enclosed internodes. Thus, E. meghalayensis only occurred in open phytotelmata, and E. jaechi was just found in a rock pool, a bamboo stump and a dead internode possessing a very large opening (Fig. 15). The reason for this may be that species living in open phytotelmata possibly use reflections of the water surface in order to detect their habitats. Species living in enclosed internodes probably employ a different search strategy, since they need to approach bamboo culms, walk along stems and search for small entrance holes in order to find a water-filled internode.

Our results indicate that single internodes were usually colonized just by one species, but occasionally two Exochomoscirtes species were found in the same phytotelm, for example, E. hajeki and E. hashimi spec. nov. (dead internode), E. hajeki and E. cf. luteosuturaloides (dead internode) or E. chiangmaiensis and E. carinensis (bamboo stump).

Exochomoscirtes living in open phytotelms constructed pupal chambers in the vicinity of their habitats (E. meghalayensis, E.chiangmaiensis/carinensis), while those developing in enclosed bamboo internodes pupated attached to the bamboo wall of the internode cavity (E. cf. luteosuturaloides, E. hajeki and E. hashimi spec. nov.). Occasionally, they started to build pupal chambers prior to pupation, but they rarely finished them, although construction material was available. Therefore, some pupae were enclosed by a detritus wall rather than a pupal chamber (Fig. 21). It may be that Exochomoscirtes living in enclosed and dark internodes were less vulnerable to predation and therefore could afford to give up constructing pupal chambers.

The length of the life cycle was roughly estimated for E. hajeki. In two cases the period between detection of a 
female possibly laying eggs and eclosion of the first adult of the next generation lasted 88 and 95 days, i.e., the total development time was about 3 months or longer.

The main predators of Exochomoscirtes inhabiting enclosed bamboo internodes were Toxorhynchites mosquito larvae and jumping or web-building spiders (Table 3). Exochomoscirtes were most often captured in the submerged larval stage, followed by larvae staying on land, pupae and adults (Table 3). Larvae staying on land were probably less vulnerable to predators then submerged ones, because they did not move much. Pupae also usually did not move and were partially protected by their shed exuviae or sometimes a detritus wall. Finally, adults were probably less vulnerable to predators because of their hard cuticle and their ability to jump.

In summary, our results show that bamboo phytotelmata provide a major habitat for Exochomoscirtes and that bamboo scirtids would merit further investigation.

\section{Acknowledgments}

This work is part of a research project which was funded by the Deutsche Forschungsgemeinschaft and supported by the Socio-Economic Research Unit of the Government of Malaysia and Universiti Malaya. Thanks are due to I. Azarae and R. Hashim for making available facilities at the Ulu Gombak Field Studies Centre and to D. Wiwatwitaya for his support in Thailand.

\section{References}

Klausnitzer, B. 2009: Insecta: Coleoptera: Scirtidae. (Die Scirtidae der Westpaläarktis). - In: Süßwasserfauna von Mitteleuropa. Begründet von A. BRAUER, herausgegeben von P. ZwICK. Band 20/17. - Spektrum Akademischer Verlag, Heidelberg: 326 S., 1041 Abb., 8 Farbtafeln.

Klausnitzer, B. 2010a: Zur Kenntnis der in Laos vorkommenden Scirtidae (Coleoptera). Teil 1 (151. Beitrag zur Kenntnis der Scirtidae). - Beiträge zur Entomologie 60 (1): 213-228.

Klausnitzer, B. 2010b: Zur Kenntnis der Gattung Exochomoscirtes PIC, 1916 (Coleoptera, Scirtidae) (153. Beitrag zur Kenntnis der Scirtidae). - Beiträge zur Entomologie 60 (2): 281-293.

Klausnitzer, B. 2010c: Neue gelb-schwarz gezeichnete Arten aus der Gattung Exochomoscirtes PIC 1916 (Coleoptera, Scirtidae) (154. Beitrag zur Kenntnis der Scirtidae). - Linzer biologische Beiträge 42 (2): 1363-1371.
Kovac, D. \& Krocke, M. 2013: Biology of the bambooinhabiting semi-aquatic bugs Lathriovelia rickmersi Kovac \& YANG and L. capitata Andersen (Insecta: Heteroptera: Veliidae) and habitat specialisation in the Oriental Baptista / Lathriovelia complex. - The Raffles Bulletin of Zoology Supplement 29: 49-70.

Kovac, D. \& Matile, L. 1997: Truplaya ferox (Insecta: Diptera: Mycetophiloidea), a new Malaysian Keroplatid from bamboo phytotelmata with larvae predaceous on ants. - The Raffles Bulletin of Zoology 45 (1): 15-28.

Kovac, D. \& Streit, B. 1996: The arthropod community in bamboo internodes in Peninsular Malaysia: Microzonation and trophic structure. Pp. 85-99. - In: Edwards, D. S.; Воотн, W. E. \& Choy, S. C. (eds.): Tropical Rainforest Research. - Current Issues: 570 pp.

RutA, R. 2011a: A new species of Exochomoscirtes PIC from Thailand (Coleoptera: Scirtidae). - Genus 22 (1): 23-28.

Ruta, R. 2011b: Two New Species and New Records of Exochomoscirtes Pic (Coleoptera, Scirtidae). - The Japanese Journal of Systematic Entomology 17 (2): 421-427.

Ruta, R. \& Yoshitomi, H. 2010: Revision of the genus Exochomoscirtes PIC (Coleoptera: Scirtidae: Scirtinae). - Zootaxa (Monograph) 2598: 1-80.

WATts, C. H. S. 2004: Revision of Australian Scirtes Illiger and Ora Clark (Coleoptera: Scirtidae). Transactions of the Royal Society of South Australia 128 (1): 131-167.

Yosнiтомi, H. 2008: Redescriptions of the Type Material of Eight Scirtid Species (Insecta, Coleoptera) in the Hope Entomological Collections in Oxford. - The Japanese Journal of Systematic Entomology 14 (2): 295-309.

ZABKA, M. \& KovaC, D. 1996: Paracyrba wanlessi - a new genus and species of Spartaeinae from Peninsular Malaysia, with notes on its biology. - Senckenbergiana biologica 76 (1/2): 153-161.

Zwick, P. 2011: Some Scirtidae (Coleoptera) from Palawan (the Philippines), mainly from phytotelmata. - Aquatic Insects 33 (3): 233-252. 


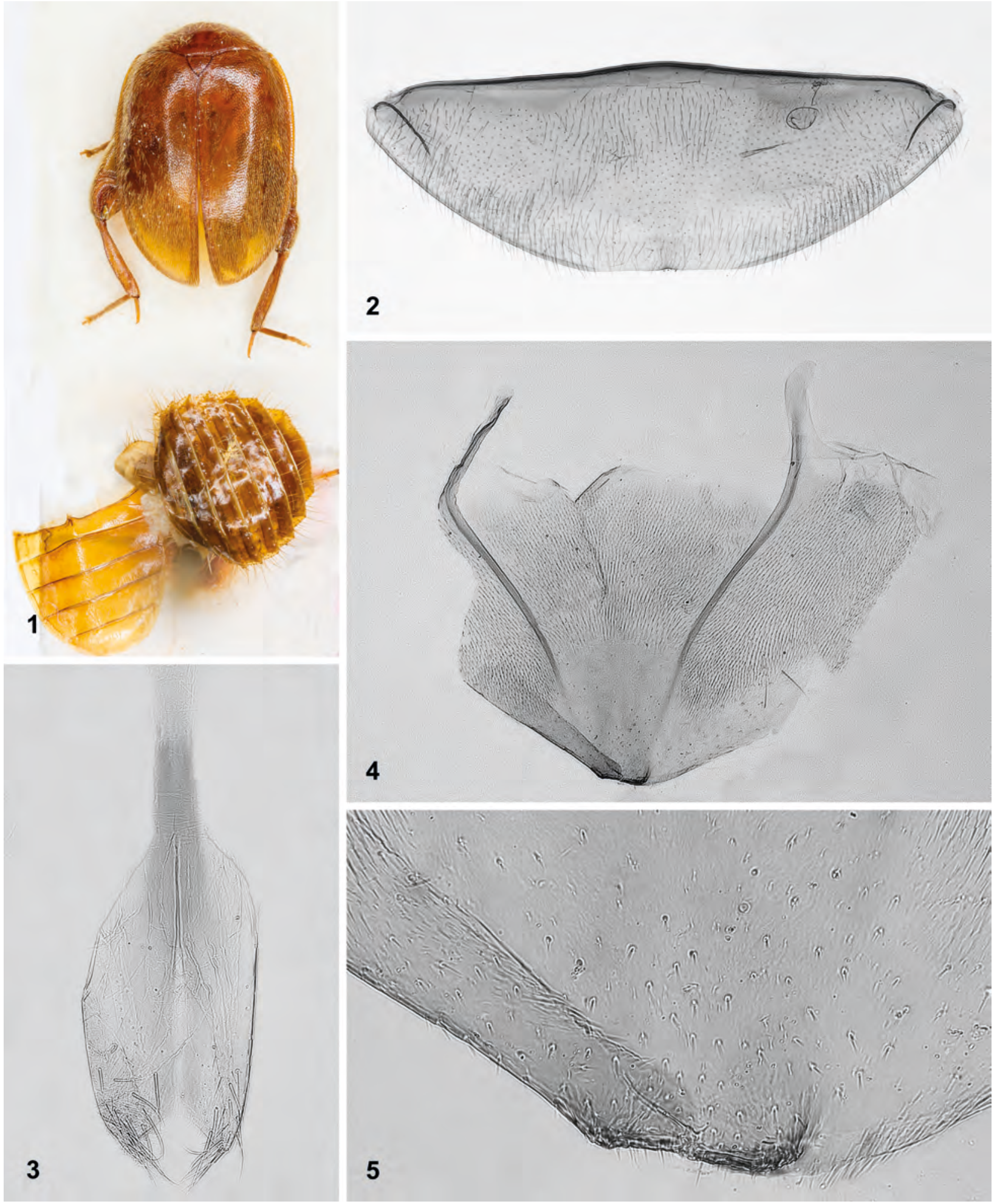

Figs 1-5: Exochomoscirtes hashimi spec. nov.: (1) Habitus, dorsal, including exuviae and detached abdomen; (2) Sternite 7; (3) Sternite 9; (4) Tergite 7; (5) Tergite 7, posterior margin. 

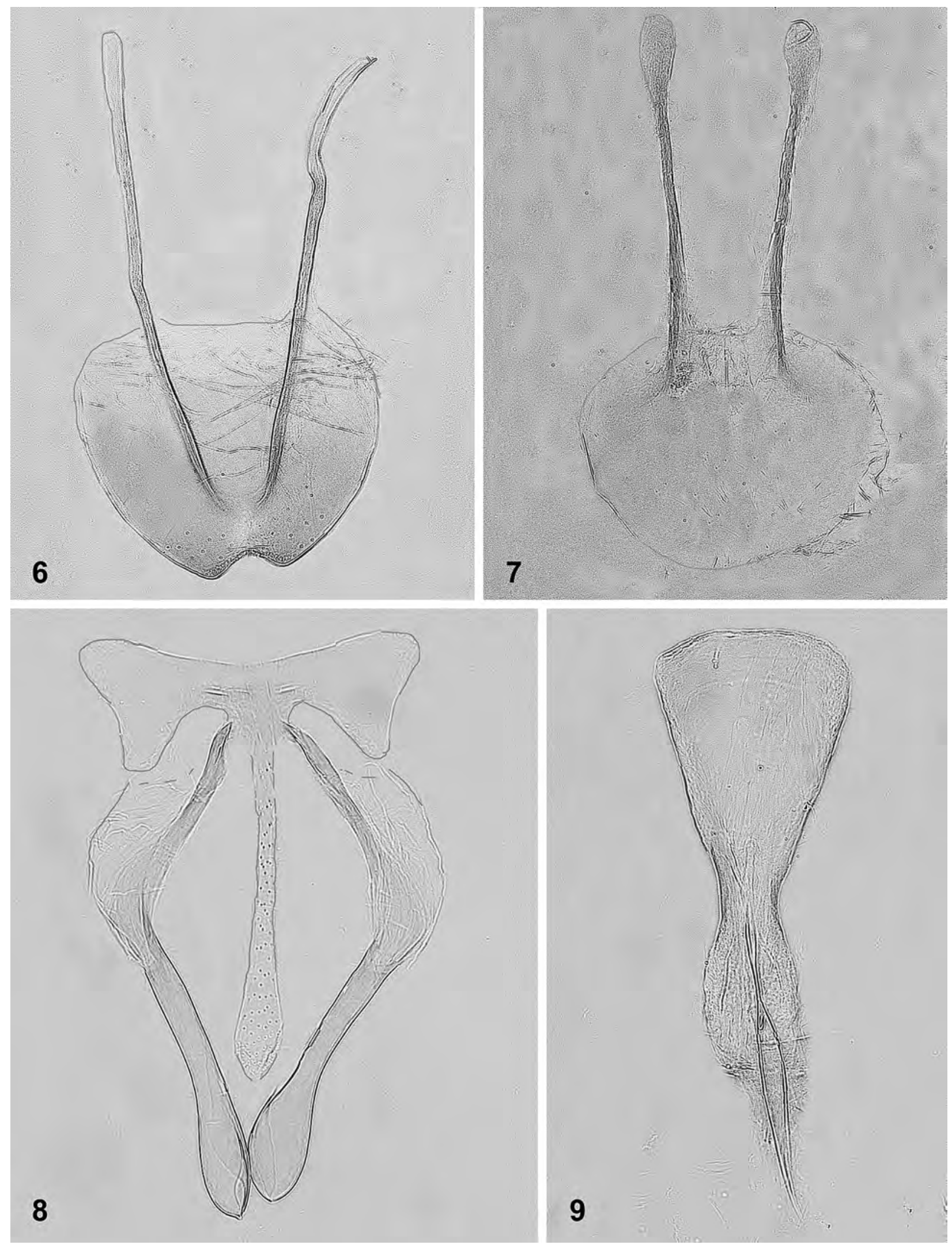

Figs 6-9: Exochomoscirtes hashimi spec. nov.: (6) Tergite 8; (7) Tergite 9; (8) Tegmen; (9) Penis. 

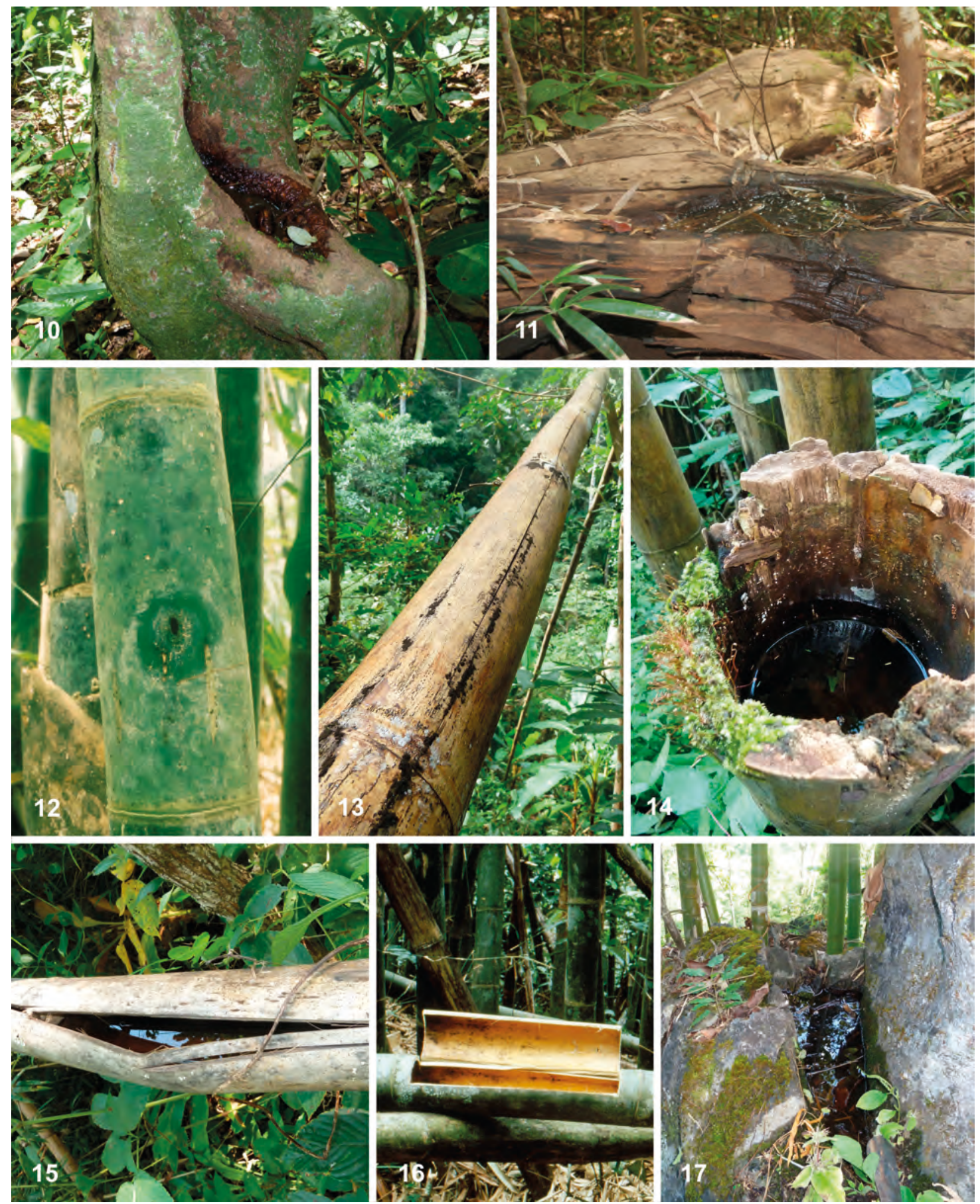

Figs 10-17: Exochomoscirtes habitats in Malaysia (Figs 12, 16) and Thailand (Figs 10, 11, 13-15, 17). Species found in depicted habitat types are bracketed. (10) Water-filled tree hole (E. meghalayensis). (11) Water-filled depression in a fallen tree (E. meghalayensis). (12) Internode of a living bamboo culm provided with an exit hole of the leaf beetle Lasiochola goryi (E. hashimi spec. nov.). (13) Fallen, decaying bamboo culm with a slit used as entrance (E. hajeki, E. hashimi n. sp.). (14) Water-filled bamboo stump (E. chiangmaiensis, E. carinensis). (15) Decaying bamboo culm with large opening (E. jaechi, E. chiangmaiensis/carinensis). (16) "Experimental internode" which could be opened for inspection (E. hashimi spec. nov., E. hajeki, E. cf. luteosuturaloides). (17) Forest rock pool (E. meghalayensis). 

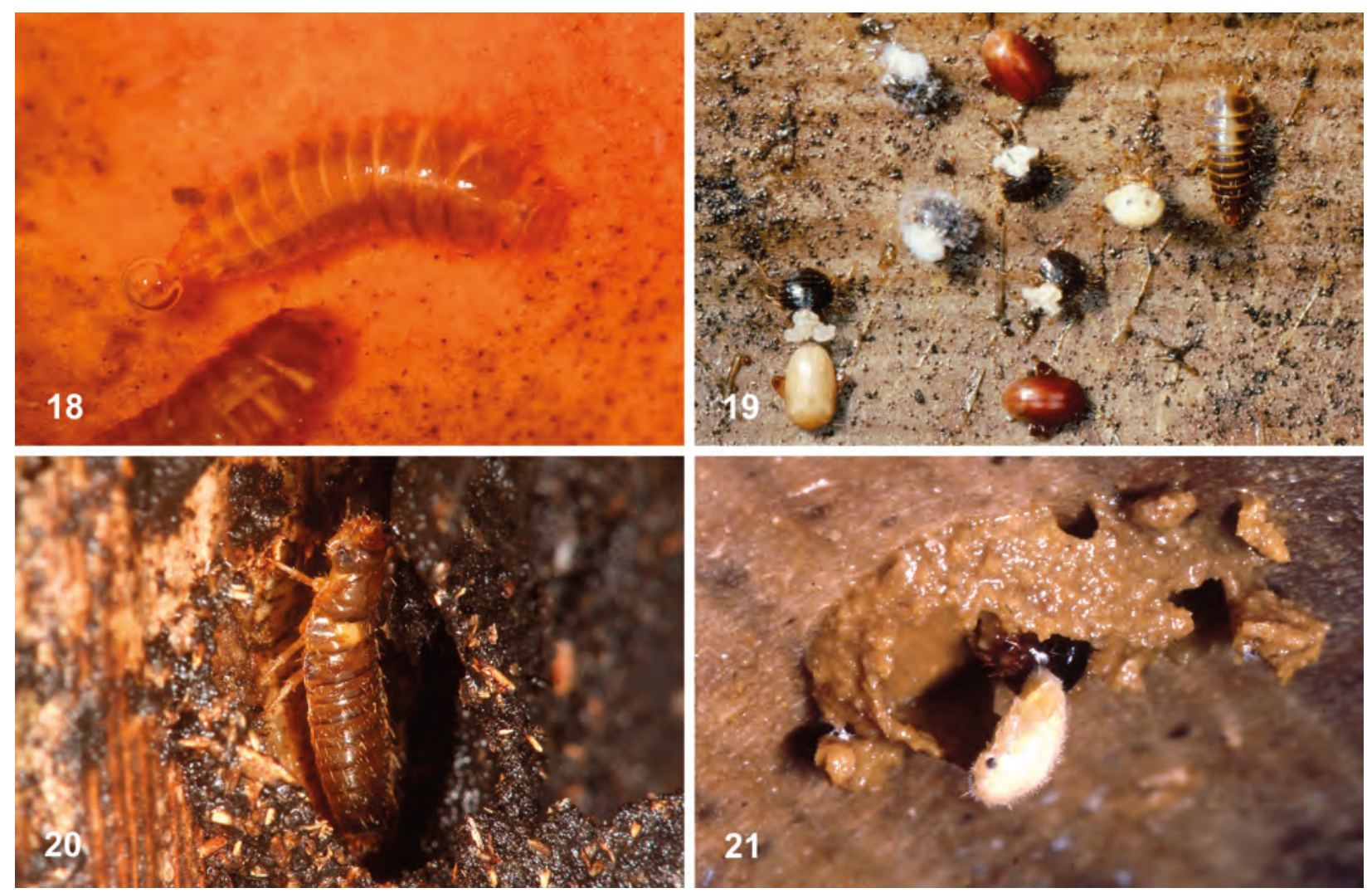

Figs 18-21: Developmental stages of Exochomoscirtes. (18) E. hajeki, submerged larva. Note the long antennae and the air bubble at the tip of abdomen. (19) E. hashimi spec. nov., developmental stages seen on bamboo wall above the water surface: one larva ready for pupation, one pupa, two freshly emerged adults, one pale adult still connected to larval exuvia, four exuviae remains. (20) E. chiangmaiensis/ carinensis larva with broken off antennae, enveloped by a pupal chamber made of debris (front part of pupal chamber removed). (21) E. hajeki pupa attached to the bamboo wall inside the unfinished pupal chamber. 
Tab. 1: Comparison between Exochomoscirtes hashimi spec. nov. and two similar species possessing a rectangular process on tergite 7 , E. retusus and E. ruforotundus. Characters referring to E. retusus were adopted from the redescription presented by Yoshiтomi (2008), E. ruforotundus characters were taken from the original description and from RUTA \& Yoshitomi (2010). Measurements in $\mathrm{mm}$.

\begin{tabular}{|c|c|c|c|}
\hline Characters & E. retusus & E. ruforotundus & E. hashimi spec. nov. \\
\hline Parameres & $\begin{array}{l}\text { long, slender, gently arcuate in } \\
\text { proximal half, apex expanded } \\
\text { triangularly in apical part }\end{array}$ & $\begin{array}{l}\text { thin, sinuate, apex bulbous } \\
\text { at tips }\end{array}$ & $\begin{array}{l}\text { directed outward, approxima- } \\
\text { tely half-way angled inwards } \\
\text { (Fig. } 8 \text { ), apex lobe-shaped) }\end{array}$ \\
\hline Tegmen & L $0.42 ; \mathrm{W} 0.20$ & L $0.47 ; \mathrm{W} 0.23$ & L $0.43 ; \mathrm{W} 0.36$ \\
\hline $\begin{array}{l}\text { Tergite } 7 \text {, posterior } \\
\text { edge }\end{array}$ & apex with a small projection & apex with a small projection & $\begin{array}{l}\text { apex with elevated and trun- } \\
\text { cated sclerotized edge (Figs } 4,5 \text { ) }\end{array}$ \\
\hline Tergite 8 & L $0.49 ; \mathrm{W} 0.37$ & L $0.51 ; 0.37$ & L 1.05; W 0.53 \\
\hline $\begin{array}{l}\text { Tergite } 8 \text {, posterior } \\
\text { edge }\end{array}$ & almost straight & almost straight & $\begin{array}{l}\text { indentation (depth } 0,04 \mathrm{~mm} \text { ) } \\
\text { covered with small teeth (Fig. 6) }\end{array}$ \\
\hline Index L:W & 1.32 & 1.38 & 1.98 \\
\hline Tergite 9 & L 0.50; W 0.21 & L $0.55 ;$ W 0.28 & L 0.60; W 0.31 \\
\hline Sternite 9 & L $0.38 ; \mathrm{W} 0.17$ & L $0.42 ; \mathrm{W} 0.19$ & L $0.47 ; \mathrm{W} 0.18$ \\
\hline Penis & L $0.35 ; \mathrm{W} 0.14$ & L $0.45 ; \mathrm{W} 0.15$ & L $0.36 ; \mathrm{W} 0.13$ \\
\hline $\begin{array}{l}\text { Metatibia, dorsal } \\
\text { spur }\end{array}$ & gently curved laterally & relatively long, broad & $\begin{array}{l}\text { straight, only apex weakly } \\
\text { curved, L } 0.47\end{array}$ \\
\hline Body length & 3.88 & $3.2-4.7$ & 4.72 \\
\hline $\begin{array}{l}\text { Body length/greatest } \\
\text { width }\end{array}$ & 1.35 & & 1.50 \\
\hline Distribution & Indonesia (Ceram) & Australia, New Guinea, Bali & Malaysia \\
\hline
\end{tabular}

Tab. 2: Habitats of Exochomoscirtes species recorded in the present study. Numerals indicate the number of phytotelmata from which larvae were reared or in which adults emerged during the long term studies. Females of E. chiangmaiensis and E. carinensis could not be differentiated. The six E. hashimi spec. nov. from mature bamboo culms were observed by an endoscope.

\begin{tabular}{|c|c|c|c|c|c|c|c|}
\hline Exochomoscirtes species & $\begin{array}{l}\text { Bamboo } \\
\text { shoots }\end{array}$ & $\begin{array}{l}\text { Mature } \\
\text { bamboo culms }\end{array}$ & $\begin{array}{l}\text { Dead bamboo } \\
\text { culms }\end{array}$ & $\begin{array}{l}\text { Bamboo } \\
\text { stumps }\end{array}$ & $\begin{array}{l}\text { Tree } \\
\text { holes }\end{array}$ & $\begin{array}{l}\text { Depressions } \\
\text { in fallen trees }\end{array}$ & $\begin{array}{l}\text { Rock } \\
\text { pools }\end{array}$ \\
\hline Thailand & & & & & - & & \\
\hline E. hajeki & - & - & 12 & 1 & - & - & - \\
\hline E. jaechi & - & - & 1 & 1 & - & - & 1 \\
\hline E. chiangmaiensis & - & - & 1 & 1 & - & - & - \\
\hline E. carinensis & - & - & - & 1 & - & - & - \\
\hline $\begin{array}{l}\text { E. chiangmaiensis or } \\
\text { carinensis }\end{array}$ & - & - & - & 3 & - & - & - \\
\hline E. meghalayensis & - & - & - & - & 3 & 1 & 3 \\
\hline \multicolumn{8}{|l|}{ Malaysia } \\
\hline E. hajeki & - & - & 36 & - & - & - & - \\
\hline E. hashimi spec. nov. & - & 6 & 20 & - & - & - & - \\
\hline E. cf. luteosuturaloides & - & 1 & 2 & - & - & - & - \\
\hline
\end{tabular}


Tab. 3: Aquatic, semiaquatic and terrestrial predators preying upon Exochomoscirtes in internode cavities of dead or living bamboo culms in West Malaysia. The captured Exochomoscirtes adults belonged to E. cf. luteosuturaloides, E. hajeki and E. hashimi spec. nov. Numerals indicate the number of prey items collected from experimental internodes or observed by an endoscope in living culms.

\begin{tabular}{|l|c|c|c|c|}
\hline Predators & $\begin{array}{l}\text { Exochomoscirtes } \\
\text { larva submerged }\end{array}$ & $\begin{array}{l}\text { Exochomoscirtes } \\
\text { larva on land }\end{array}$ & $\begin{array}{l}\text { Exochomoscirtes } \\
\text { pupa }\end{array}$ & $\begin{array}{l}\text { Exochomoscirtes } \\
\text { imago }\end{array}$ \\
\hline Dead bamboo culms & 1 & - & - & - \\
\hline Dasyhelea spec. & 12 & - & - & - \\
\hline $\begin{array}{l}\text { Toxorhynchites metallicus and } \\
\text { T. leicesteri }\end{array}$ & 2 & - & - & 1 \\
\hline Lathriovelia rickmersi & 8 & 1 & 2 & - \\
\hline Paracyrba wanlessi & - & - & 6 & - \\
\hline Acylophorus spec. & - & 9 & - & - \\
\hline Theridiidae & - & - & - & 2 \\
\hline Mature bamboo culms & 5 & - & - & - \\
\hline Toxorhynchites magnificus & - & 2 & & \\
\hline Truplaya ferox & - & & - & - \\
\hline Theridiidae & & - & - & - \\
\hline
\end{tabular}

